\title{
PENYULUHAN METODE CERAMAH TERHADAP PENGETAHUAN IBU TENTANG ASUPAN SAYUR DAN BUAH ANAK SD
}

\author{
Hapzah $^{\bowtie}$, Nurbaya \\ Jurusan Gizi Poltekkes Kemenkes Mamuju
}

\begin{tabular}{l} 
ARTICLE INFO \\
\hline Article history \\
Submitted : 2020-04-10 \\
Revised : 2021-07-07 \\
Accepted : 2021-07-24 \\
Keywords: \\
Nutrition \\
The nutrition counseling \\
The primary school
\end{tabular}

Kata Kunci:

Gizi

Penyuluhan Gizi

Sekolah Dasar

\begin{abstract}
ABS TRACT
Several studies have suggested that applying patterns of consumption of vegetables and fruit since children will positively contribute to vegetable and fruit intake through adolescence and adulthood. Therefore, efforts to increase vegetable and fruit intake since childhood urgent. Azria and Husnah's research results (2016) show that there is an influence of counseling on behavioral changes about balanced nutrition in infants. The results of Afif and Sumarmi (2017) research also show that there is a relationship between the role of mothers as educators with consumption of fruit vegetables in children associated with the supply of vegetables and fruit at home. The purpose of this study was to determine the effect of nutrition counseling on lecture and discussion methods on mother's knowledge of vegetable and fruit intake in elementary school children in Mamuju Regency. This type of research is experimental. This research was conducted at 001 Mamuju Public Elementary School as the location of the control group and Rimuku Inpres Elementary School as the location of the intervention group. The sample was divided into two groups, the first group as an intervention group was given lecture nutrition counseling accompanied by discussion while the second group as a control group was given lecture counseling counseling without discussion of mothers of elementary school children. The number of samples were 30 control groups and 30 intervention groups so that the total sample was 60 people. The results showed that there was an influence of lecture nutrition counseling accompanied by a discussion of mother's knowledge about vegetable and fruit intake in elementary school children ( $\mathrm{p}$ $<0.05$ ). It is expected that nutrition counseling is carried out through lecture methods accompanied by discussions to increase mothers' knowledge about vegetable and fruit intake in elementary school children.

Beberapa penelitian menunjukkan bahwa penerapan pola konsumsi sayur dan buah sejak anak akan memberikan kontribusi positif terhadap asupan sayur dan buah hingga remaja dan dewasa. Oleh karena itu, upaya peningkatan asupan sayur dan buah sejak kecil sangat mendesak. Hasil penelitian Azria dan Husnah (2016) menunjukkan bahwa ada pengaruh penyuluhan terhadap perubahan perilaku tentang gizi seimbang pada balita. Hasil penelitian Afif dan Sumarmi (2017) juga menunjukkan bahwa ada hubungan antara peran ibu sebagai pendidik dengan konsumsi sayur buah pada anak terkait dengan persediaan sayur dan buah di rumah. Tujuan penelitian ini adalah untuk mengetahui pengaruh penyuluhan gizi metode ceramah dan diskusi terhadap pengetahuan ibu tentang asupan say ur dan buah pada anak sekolah dasar di Kabupaten Mamuju. Jenis penelitian ini adalah eksperimen. Penelitian ini dilakukan di SDN 001 Mamuju sebagai lokasi kelompok kontrol dan SDN Rimuku Inpres sebagai lokasi kelompok intervensi. Sampel dibagi menjadi dua kelompok, kelompok pertama sebagai kelompok intervensi diberikan penyuluhan penyuluhan gizi disertai diskusi sedangkan kelompok kedua sebagai kelompok kontrol diberikan penyuluhan penyuluhan ceramah tanpa diskusi ibu-ibu anak SD. Jumlah sampel adalah 30 kelompok kontrol dan 30 kelompok intervensi sehingga jumlah sampel sebanyak 60 orang. Hasil penelitian menunjukkan bahwa ada pengaruh ceramah penyuluhan gizi disertai diskusi pengetahuan ibu tentang asupan sayur dan buah pada anak sekolah dasar $(\mathrm{p}<0,05)$. Diharapkan penyuluhan gizi dilakukan melalui metode ceramah disertai diskusi untuk meningkatkan pengetahuan ibu tentang asup an sayur dan buah pada anak sekolah dasar.
\end{abstract}




\section{PENDAHULUAN}

Masalah gizi kurang dan buruk di Indonesia masih menjadi masalah kesehatan masyarakat prevalensi tinggi. Terdapat tiga provinsi termasuk kategori prevalensi sangat tinggi yaitu Sulawesi Barat, Papua Barat dan Nusa Tenggara Timur dari 33 provinsi di Indonesia. Prevalensi gizi kurang dan buruk di Sulawesi Barat menurut indikator $\mathrm{BB} / \mathrm{U}$ sebanyak $\geq 30 \%$, dan prevalensi gizi kurang menurut indikator $\mathrm{TB} / \mathrm{U}$ sebanyak $\geq 50 \%$, sedangkan menurut WHO (2010) prevalensi sangat tinggi jika $\geq 30 \%$ (Kementerian Kesehatan RI, 2013). Status gizi secara langsung dipengaruhi oleh asupan makan. Konsumsi sayur dan buah yang cukup dapat melindungi kesehatan tubuh, termasuk dalam menjaga berat badan (Mitchell, 2012).

Membiasakan anak untuk mengonsumsi sayur dan buah sejak dini sangat penting karena pola diet yang diterapkan pada usia anak-anak akan mempengaruhi pola diet ketika dewasa, jika ketika masih anak-anak memiliki pola diet yang buruk maka hingga dewasa pun akan tetap buruk dan akan mempengaruhi kesehatannya. Penelitian Demitri dkk (2015) pada anak Sekolah Dasar Negeri (SDN) Kota Medan menunjukkan bahwa sebelum dilakukan pendidikan gizi melalui game puzzle pada anak, kategori pengetahuan kurang baik sebesar 26,7\%, setelah dilakukan pendidikan gizi tidak ada lagi anak dalam kategori pengetahuan kurang baik. Hasil penelitian tersebut menunjukkan bahwa masih ditemukan anak yang memiliki pengetahuan gizi yang rendah. Kemudian hasil penelitian lain menunjukkan bahwa terdapat pengaruh penyuluhan dengan metode ceramah tentang gizi seimbang terhadap anak Sekolah Dasar (Geraldy, 2019).

Upaya pendidikan gizi ternyata efektif untuk meningkatkan pengetahuan gizi anak, namun pada penelitian penyuluhan gizi ini dilakukan terhadap ibu anak sehingga asupan gizi anak lebih meningkat (Demitri, 2015). Hasil penelitian Afif dan Sumarmi (2017) juga menunjukkan ada hubungan peran ibu sebagai edukator dengan konsumsi sayur buah pada anak yang dikaitkan dengan penyediaan sayur dan buah di rumah. Penelitian ini bertujuan untuk melihat pengaruh penyuluhan pada ibu tentang asupan sayur dan buah pada anak Sekolah Dasar melalui metode ceramah disertai diskusi.

\section{METODE PENELITIAN Jenis penelitian}

Jenis Penelitian yang digunakan dalam penelitian ini adalah penelitian eksperimen. Sampel dibagi dalam 2 kelompok yaitu kelompok intervensi dan kelompok kontrol. Kelompok intervensi diberikan penyuluhan gizi melalui metode ceramah disertai diskusi terhadap ibu dari siswa Sekolah Dasar sedangkan kelompok kontrol juga diberikan penyuluhan gizi melalui metode ceramah tanpa disertai diskusi. Penelitian bertujuan untuk melihat perbedaan peningkatan pengetahuan antara kelompok ibu yang memperoleh penyuluhan melalui metode ceramah dengan kelompok ibu yang memperoleh penyuluhan melalui metode ceramah disertai diskusi.

\section{Lokasi dan Waktu Penelitian}

Lokasi penelitian dilaksanakan di SD Inpres Rimuku sebagai tempat penelitian dari kelompok intervensi, dan SDN 001 Mamuju sebagai tempat penelitian dari kelompok kontrol. Penelitian dilakukan pada Bulan Maret sampai dengan Bulan Oktober 2019.

\section{Populasi dan Sampel}

Populasi pada penelitian ini adalah anak Sekolah Dasar di SD Inpres Rimuku dan SD Negeri 001 Mamuju Kabupaten Mamuju tahun 2019. Jumlah sampel sebanyak 60 anak yaitu 30 anak pada kelompok intervensi dan 30 anak pada kelompok kontrol.

\section{Pengumpulan Data}

Data tentang karakteristik umum anak SD dikumpulkan secara langsung oleh petugas lapangan dengan berpedoman pada kuesioner dengan cara wawancara terhadap anak. Data pengetahuan Ibu tentang asupan sayur dan buah pada anak Sekolah Dasar diperoleh dengan menggunakan kuesioner.

Pengumpulan data pengetahuan ibu dilakukan sesaat sebelum penyuluhan sebagai data pretest. Setelah penyuluhan dilakukan kembali pengumpulan data pengetahuan ibu sebagai data posttest.

\section{Pengolahan dan Analisis Data}

Data karakteristik umum responden, dan pengetahuan ibu diolah secara komputerisasi kemudian data dianalisa dengan menggunakan uji Mann-Whitney untuk melihat perbedaan peningkatan pengetahuan antara kelompok 
yang memperoleh penyuluhan metode ceramah dengan kelompok yang memperoleh penyuluhan metode ceramah disertai diskusi.

\section{HASIL PENELITIAN}

Tabel 1 menunjukkan bahwa sebelum intervensi tidak terdapat perbedaan yang bermakna berdasarkan uji t independent antara dua kelompok baik dilihat dari aspek pendidikan ayah, pendidikan ibu, pekerjaan ayah, pekerjaan ibu, dan jumlah anggota keluarga $(p>0,05)$.

Tabel 1. Karakteristik Umum Responden berdasarkan Pendidikan Terakhir Ayah dan Ibu, Pekerjaan Ayah dan Ibu, dan Jumlah Anggota Keluarga

\begin{tabular}{|c|c|c|c|c|c|}
\hline \multirow{2}{*}{ Karakteris tik Responden } & \multicolumn{2}{|c|}{ Kelompok Kontrol } & \multicolumn{2}{|c|}{ Kelompok Intervensi } & \multirow{2}{*}{$p^{a}$} \\
\hline & $\mathrm{n}=\mathbf{3 0}$ & $\%$ & $\mathrm{n}=\mathbf{3 0}$ & $\%$ & \\
\hline \multicolumn{6}{|l|}{ Pendidikan Ayah } \\
\hline Sekolah Dasar & 1 & 3,3 & 1 & 3,3 & \multirow{4}{*}{0,609} \\
\hline SLTP & 2 & 6,7 & 1 & 3,3 & \\
\hline SLTA & 9 & 30,0 & 8 & 26,7 & \\
\hline PT & 18 & 60,0 & 20 & 66,7 & \\
\hline \multicolumn{6}{|l|}{ Pendidikan Ibu } \\
\hline Sekolah Dasar & 0 & 0,0 & 1 & 3,3 & \multirow{4}{*}{0,627} \\
\hline SLTP & 6 & 20,0 & 2 & 6,7 & \\
\hline SLTA & 4 & 13,3 & 12 & 40,0 & \\
\hline $\mathrm{PT}$ & 20 & 66,7 & 15 & 50,0 & \\
\hline \multicolumn{6}{|l|}{ Pekerjaan Ayah } \\
\hline PNS & 14 & 46,6 & 7 & 23,3 & \multirow{6}{*}{0,252} \\
\hline Wiraswasta & 14 & 46,6 & 14 & 46,6 & \\
\hline Pegawai Non PNS & 1 & 3,3 & 7 & 23,3 & \\
\hline Petani & 0 & 0,0 & 1 & 3,3 & \\
\hline Buruh & 1 & 3,3 & 0 & 0,0 & \\
\hline Nelayan & 0 & 0,0 & 1 & 3,3 & \\
\hline \multicolumn{6}{|l|}{ Pekerjaan Ibu } \\
\hline PNS & 8 & 26,7 & 10 & 33,3 & \multirow{4}{*}{0,443} \\
\hline Wiraswasta & 4 & 13,3 & 4 & 13,3 & \\
\hline Pegawai Non PNS & 1 & 3,3 & 2 & 6,7 & \\
\hline URT & 17 & 56,7 & 14 & 46,7 & \\
\hline \multicolumn{6}{|l|}{ Jumlah Anggota Keluarga } \\
\hline$\leq 4$ & 16 & 53,3 & 13 & 43,3 & \multirow{2}{*}{0,100} \\
\hline$>4$ & 14 & 46,7 & 17 & 56,7 & \\
\hline
\end{tabular}

Tabel 2 menunjukkan bahwa sebelum intervensi rata-rata pengetahuan kelompok intervensi lebih rendah daripada kelompok kontrol, tetapi setelah intervensi rata-rata pengetahuan kelompok intervensi lebih tinggi dibandingkan dengan kelompok kontrol. Terdapat perbedaan peningkatan pengetahuan antara kedua kelompok berdasarkan hasil uji mann-whitney $(\mathrm{p}<0,05)$. Hal ini berarti bahwa penyuluhan melalui metode ceramah disertai diskusi lebih efektif meningkatkan pengetahuan ibu tentang asupan sayur dan buah anak sekolah dasar dibandingkan metode penyuluhan dengan melalui ceramah tanpa disertai diskusi.

\section{PEMBAHASAN}

Penelitian ini bertujuan untuk melihat pengaruh penyuluhan gizi metode ceramah terhadap pengetahuan ibu tentang asupan sayur dan buah pada anak SD di Kabupaten Mamuju. Sampel dibagi dalam 2 kelompok yaitu kelompok pertama sebagai kelompok intervensi yaitu siswa yang terdapat di SD Inpres Rimuku Mamuju. Dimana ibu dari kelompok intervensi mendapatkan penyuluhan melalui metode ceramah yang disertai dengan diskusi. Adapun Kelompok kedua sebagai kelompok kontrol yaitu anak siswa dari SDN 001 Mamuju. Di mana ibu dari kelompok kontrol mendapatkan 
penyuluhan melalui metode ceramah tanpa disertai dengan diskusi. Hasil penelitian menunjukkan bahwa karakteristik umum keluarga siswa yaitu pekerjaan dan pendidikan ayah dan ibu serta jumlah anggota keluarga siswa tidak berbeda secara statistik ( $p>0.05$ ).

Tabel 2 Perbedaan Peningkatan Pengetahuan Ibu tentang Asupan Sayur dan Buah pada Anak Sekolah Dasar Sebelum dan Sesudah Penyuluhan pada Kelompok Intervensi dan Kelompok Kontrol

\begin{tabular}{lcccccc}
\hline Kelompok & $\begin{array}{c}\text { Sebelum } \\
\text { Intervensi }\end{array}$ & $\boldsymbol{p}$ & $\begin{array}{c}\text { Sesudah } \\
\text { Intervensi }\end{array}$ & $\boldsymbol{p}$ & Peningkatan & $\boldsymbol{p}$ \\
\hline Kontrol & 34,23 & 0.091 & 27,72 & 0.208 & 21,80 & 0.000 \\
Intervensi & 26,77 & $0.09,28$ & 39,20 & 0.000 \\
\hline
\end{tabular}

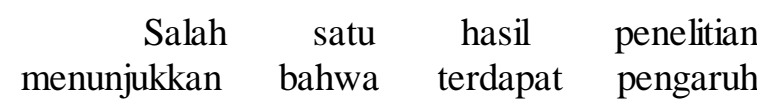
penyuluhan terhadap perubahan perilaku tentang gizi seimbang pada balita (Azria, 2016). Hasil penelitian Afif dan Sumarmi (2017) juga menunjukkan ada hubungan peran ibu sebagai edukator dengan konsumsi sayur buah pada anak yang dikaitkan dengan penyediaan sayur dan buah di rumah. Pada hasil penelitian ini menunjukkan bahwa sebelum intervensi ratarata pengetahuan kelompok intervensi lebih rendah daripada kelompok kontrol, tetapi setelah intervensi rata-rata pengetahuan kelompok intervensi lebih tinggi dibandingkan dengan kelompok kontrol. Terdapat perbedaan peningkatan pengetahuan antara kedua kelompok berdasarkan hasil uji mann-whitney $(p<0,05)$. Hal ini berarti bahwa penyuluhan dengan metode ceramah disertai diskusi lebih efektif meningkatkan pengetahuan ibu tentang asupan sayur dan buah daripada penyuluhan dengan metode ceramah tanpa disertai diskusi.

Faktor yang mempengaruhi rendahnya konsumsi sayur dan buah pada remaja juga dipengaruhi oleh faktor orang tua, yaitu keterlambatan dalam mengenalkan sayur dan buah, ketidakmampuan dalam memberikan contoh konsumsi sayur dan buah yang baik, rendahnya status sosial ekonomi serta terbatasnya ketersediaan sayur dan buah di rumah. Perilaku konsumsi sayur dan buah pada remaja juga dipengaruhi oleh beberapa faktor seperti faktor umur, jenis kelamin, preferensi/ kesukaan terhadap sayur dan buah, latar belakang budaya, uang saku, ketersediaan sayur dan buah di rumah serta pengaruh orang tua dan teman sebaya (Ramussen, 2011).

Melalui pemberian penyuluhan metode ceramah ini ibu dapat memiliki pengetahuan yang cukup tentang kebutuhan sayur dan buah.
Sebelum penyuluhan para ibu lebih banyak tidak mengetahui tentang kebutuhan sayur dan buah bagi anak usia Sekolah Dasar yaitu sekitar 400 gram setiap hari atau sekitar 3 sampai 4 porsi sehari. Melalui ceramah para ibu mengetahui tentang manfaat dan kebutuhan sayur dan buah setiap hari. Kemudian pada kelompok intervensi yaitu kelompok yang melakukan diskusi setelah memperoleh penyuluhan melalui metode ceramah saling share pengetahuan dan pengalaman terkait solusi-solusi yang biasa diterapkan dalam upaya menyediakan dan meningkatkan asupan sayur dan buah pada anak mereka. Adanya tambahan diskusi pada penyuluhan metode ceramah memberikan daya ingat dan pemahaman yang lebih mendalam kepada para ibu yang dapat dilihat dari hasil posttest setelah penyuluhan dan diskusi. Hal ini sejalan dengan Hasil penelitian Supriati (2016) yang menunjukkan bahwa melalui diskusi ibu memperoleh informasi yang tepat dan melibatkan pendapat ibu, sehingga diskusi dianggap efektif dalam meningkatkan pengetahuan dan sikap ibu.

Hasil penelitian Lubis (2013) menunjukkan bahwa metode diskusi dianggap efektif digunakan dibandingkan dengan ceramah. Hal ini disebabkan karena pada metode diskusi semua peserta terlibat dalam menyatakan pendapatnya dan pengalamannya, serta membahas materi yang diberikan sampai memperoleh kesimpulan yang sesuai.

\section{KESIMPULAN DAN SARAN}

Penyuluhan gizi melalui metode ceramah disertai diskusi lebih efektif meningkatkan pengetahuan ibu tentang asupan sayur dan buah pada anak Sekolah Dasar dibandingkan dengan metode penyuluhan dengan hanya ceramah saja tanpa disertai diskusi $(\mathrm{p}=0.000)$. Untuk itu 
disarankan adanya diskusi yang mendalam setelah pemberian ceramah tentang asupan sayur dan buah anak SD kepada ibu.

\section{DAFTAR PUSTAKA}

Afif, S. (2017). Peran Ibu Sebagai Edukator dan Konsumsi Sayur Buah pada Anak. Amerta Nutrition, Vol. 1, No.3: 236-242.

Azria, H. (2016). Pengaruh Penyuluhan Gizi Terhadap Pengetahuandan Perilaku Ibu Tentang Gizi Seimbang Balita Kota Banda Aceh. Jurnal Kedokteran Syiah Kuala, Vol. 16, No. 2: 87-92.

Demitri, A. N. (2015). Pengaruh Pendidikan Gizi Tentang Pola Makan Seimbang Melalui Game Puzzle Terhadap Peningkatan Pengetahuan Anak SDN 067690 Kota Medan. Jurnal Gizi, Kesehatan Reproduksi dan Epidemiologi, Vol. 1 No. 2 .

Epstein-Solfield, A., Arango, C., Ogan, D., Stendell-Hollis, N., 2018. The Effects of a Nutrition Education Intervention on Third- and Fifth-Grade Students' Fruit and Vegetable Knowledge, Preference And Consumption. J. Child Nutr. Manag. 42.

Geraldy, G., Rattu, J. A., \& H Molanda, N. S. (2019). Pengaruh Penyuluhan Dengan Teknik Ceramah Terhadap Pengetahuan Pelajar tentang Gizi Seimbang di Sekolah Dasar Kecamatan Tompaso. Jurnal KESMAS, Vol. 8, Hal. 328-335.
Kementerian Kesehatan RI. (2013). Laporan Hasil Riset Kesehatan Dasar (RISKESDAS) Indonesia Tahun 2011. Jakarta.

Lubis, Z. A., Lubis, N. L., \& Syahrial, E. (2013). Pengaruh Penyuluhan Dengan Metode Ceramah dan Diskusi Terhadap Peningkatan Pengetahuan dan Sikap Anak tentang PHBS di Sekolah Dasar Negeri 065014 Kelurahan Namogajah Kecamatan Medan Tuntungan Tahun 2013. Medan: Fakultas Kesehatan Masyarakat Universitas Sumatera Utara.

Mitchell, G. L. (2012). Parental Influences on Children's Eating Behaviour and Characteristics of Successful parentFocussed Intervations. Appetite, 60 (8590).

Ramussen, M. K. (2011). Determinants of Fruit and Vegetable Consumption Among Children and Adolescents: A Review of The Literature. Part II: Qualitative Studies. International of Behavioral Nutritional.

Supriati. (2016). Pengaruh Penyuluhan dengan Metode Ceramah dan Metode Diskusi terhadap Pengetahuan dan Sikap Ibu tentang Pemberian Makanan Pendamping ASI (MP-ASI) di Desa Bintang Meriah Kecamatan Batang Kuis Tahun 2016. Medan: Fakultas Kesehatan Masyarakat Universitas Sumatera Utara. 